el-Ghurâb», d. i. "die Stadt des Raben “, "die Rabenstadt". Diese Benennung kann nun die richtige sein, da sie, im Gegensatze zum nichts bedeutenden Gurob im Arabischen einen bestimmten Sinn hat. Jedenfalls mufs man mit PEtries Transskription arabischer Namen ziemlich vorsichtig umgehen, da er z. B. Dendereh gehört haben will, wo doch, möchte ich sagen, fast ausschliefslich von den Eingeborenen Denderah ausgesprochen wird.

Dieses ist nun das für die Bearbeitung der Libyerfrage, wie mir scheint, wichtige neue Material, das ich an Bord der "Bohemia" Ihnen mitzuteilen versprochen habe. Möge es Ihnen der Beachtung wert erscheinen und bei Ihnen das Interesse an die alten Libyer, deren Land Sie bereist und durchforscht haben, wach erhalten. Mögen diese Zeilen Sie auch manchmal an unsere schöne Seereise und die auf Deck im Plaudern verbrachten Nachmittagsstunden erinnern!
Marienbad, den 6./19. Juli 1903.
W. Golenischefr.

\title{
A City of Ikhenaton in Nubia.
}

\section{By James Henry Breasted.}

In the account of his coronation left us on his great stela, by the Nubian king, Nastesen, he mentions an important city named is mentioned again in $11.22 \mathrm{f}$. where it is twice called an abbreviated form of the name ${ }^{2}$ ). There was an Amon of the place, whom this passage calls Osiris and an Isis of $\square$ (MAR., Mon. div. pl. 14 1.160) ${ }^{3}$ ). Still earlier under Taharka the same Amon is mentioned in one of the side chambers of

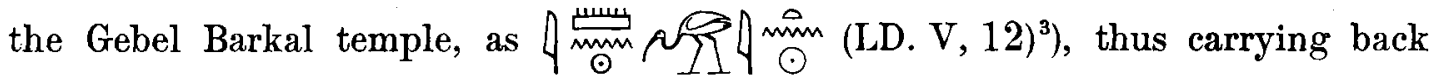
the existence of the city nearly 200 years earlier than Nastesen. There is no further mention of the place in the inscriptions and its subsequent, as well as its earlier history is totally unknown. But the origin of the city, already suggested by the occurrence of $4 \underset{\odot}{\odot}$ in its name, is rendered certain by the

1) ScнӓFFR, Die Äthiopische Königsinschrift des Berliner Museums, Leipzig 1901 (Hinrichs), p. 35, and 11. $60-61$.

2) SchäFER calls my attention to the fact that Harsiyotef on his coronation journey visited the cities in the following order: Napata, $P$-gm-itn, $P$-nbs, and Nastesen on his journey the following: Napata, $P$ - $g m, P$-nbs. Thus where one list has $P$ - $g m$-itn, the other has $P$-gm. There is therefore no doubt about the identity of the two (see Nastesen, p. 36, 8).

3) See ScräFER, Nastesen p. 35. 
hitherto unnoticed fact that the name of the Nubian eity contains part of the name of the Theban temple of $\langle\underset{\sim}{\odot}$, built by Ikhenaton.

On the façade ${ }^{1}$ ) of the well known Theban tomb of Ramose, the vizier of Ikhenaton, there is on the right of the door, a relief showing Ikhenaton and his queen worshiping, in the peculiar Amarna style, under the radiating sun-disk. They are in a building, which is not unlikely a part of the Theban temple of Aton. Outside are groups of bowing officials. In its usual form, in two cartouches the name of the god appears beside the sun-disk, but a unique addition to the name is here appended as follows:

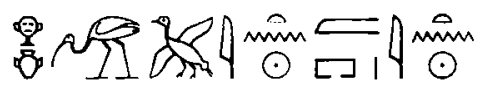

That is, with the usual introduction we have here the name of the temple in which Aton resided. I know of only one explanation of this name, viz. that of MASPERO, who renders it ml'image rouge d'Atonou dans Paatonou" (Histoire II, p. 322 note 3) $)^{2}$ ). Apart from the fact that the name does not contain the word "image ", it will be evident to every reader in view of the Nastesen passage, that we have here the $g m$-bird and not the bird for $d s r$ ("red "). The name of the Theban temple of Aton therefore furnished the name of the Nubian city, and there can be no doubt that Ikhenaton was its founder, and that he named it after the Theban temple of his god, or that form of his $\operatorname{god}^{3}$ ) who resided in the Theban temple. We have here the remarkable fact that this new Nubian city of Ikhenaton survived and still bore the name he gave it, nearly a thousand years after his death and the destruction of the new city of his god in Egypt (Amarna). Moreover, by a strange irony of fate, while the name of the Aton-city still clung to it for nearly a thousand years, its meaning was soon forgotten, as all recollection of the heresy was swept away; Amon became the chief god of the place, and the result was the remarkable incongruity, an 4 siding in the Aton-city!! This foundation of a new eity in Nubia by the heretic-king is very significant. The city was evidently in the heart of the

') It is really the inner wall of the first chamber; the outer wall having been broken out. The following notes and texts are from my own copies of the tomb. See Virliers Struar', The Funeral Tent of an Egyptian Queen p. $89 \mathrm{ff}$; Egypt after the War, pl. 27 and p. 386-388; Bourian', Rev. arch. 1882 n. s. vol. XXIII p. 279-284, and Rec. de Trav. VI 55f.; Pifal, very accurate publication of a part of the texts, $\ddot{A} Z .1883$ p.127-130; and 1887 , p. 37-39. I excavated and copied the whole tomb in Dec. 1894.

2) Following Bourian', Rev. arch. 1882 n. s. vol. XXIII p. 283.

3) What the name means is not certain; it may be simply a proposition or statement: The Aton is found in the House of Aton *, such statements commonly serving as names in ancient Egypt. But the occurrence of $g m$ 'Itn alone in souse of $g m$ 'Itna, as the name of the Nubian city, would indicate that it may have designated a form of Aton.

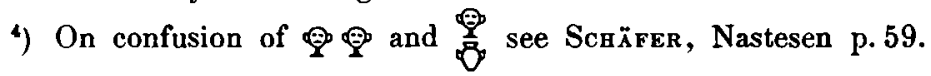


Egyptian possessions in Nubia. Nastesen left Napata on his coronation journey, and going down river proceeded to his northern frontier at (חvớ $\psi$ ) just above the second cataract and returned to Napata after an absence of not more than 36 days. On his way down to only at $\operatorname{Pr}-g m$ - I In $^{1}$ ), which must therefore have been an important place. SchäFER thinks it was probably located in the vicinity of the 3rd cataract, and certainly on the east side. It was in any case in the heart of Egypt's Nubian possessions, for they extended only to Napata, just below the fourth cataract. In the height of Egypt's power in Nubia, under Amenhotep III., the southern boundary was at Karoy as we learn from his commemorative scarabs. The location of Karoy, strangely overlooked in the histories hitherto, is determined by the inscriptions in the tomb of Hui, which give the limits of his government as viceroy of Kush thus:

and again:
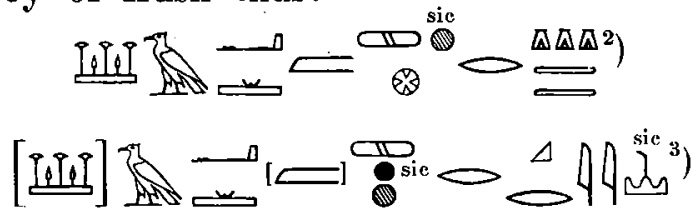

Here, as a variant of $K r j$, we have $N s w t ~ t 3 w j$ or Napata, which was thus named after Thebes $\left.{ }^{4}\right)$. This clearly locates Karoy as the district about Napata, and thus determines the southern limit of Egyptian conquest under Ikhenaton's father, a limit which was reached by Amenhotep II. and never later passed ${ }^{5}$ ).

We see therefore that Ikhenaton was attempting to make his god at home in all parts of his empire ${ }^{6}$ ), and his new Nubian foundation is an important evidence that he was striving to found a religion for his whole realm. In the great Amarna hymn, the domain of Aton, is distinctly stated to be I This statement the king evidently strove to make practically good. If then he founded a new Aton-city in Kush, called gm-'Itn, and a new Aton-city in Egypt called $y^{\prime} h w t^{-I}$ Itn, may we not expect to find a new Aton-city in Palestine, bearing a similar name? Such a name, as Sireglberg has noted ${ }^{8}$ ), does occur in the Amarna letters ${ }^{9}$ ), viz. "Hi-na-tu-na «, which may contain 'Itn, preceded by

1) See SchäFER, Nastesen p. 35.

2) Brugsch, Thes. V, 1133.

3) Ibid. 1135 .

4) The variant was noted by Brugsce also (o. c. 1139).

5) SснÄFER in his Nastesen publication is also of the opinion that Napata was the southern boundary of Egyptian Nubia, though for different reasons.

$\left.{ }^{6}\right)$ Erman suggested the same idea in 1894, Ausf. Verz. 1894 p. 6.

7) Breasted, De Hymnis in Solem p. 47 1.55.

${ }^{8}$ ) Rec. de Trav., XX $37 \mathrm{f} . \mathrm{n.1}$, and XXI 47f; he favors $\mathrm{O}^{\circ}$. The phonetic possibilities have been well discussed by Spiegelberg and need not be taken up here. See the difficulties suggested by MüLler (OLZ. I 176).

9) 11, 17 and 196,32; once with first $n$ doubled. 
the genetive $n$ and some Egyptian word like in reply to an inquiry from me, has very kindly written me, that Letter No.196, mentioning Hinatuna is probably from the reign of Amenhotep III., in which case Hinatuna could not be an Aton city.

Not merely was Ikhenaton desirous of extending the worship of his new god, from the fourth cataract of the Nile to the Upper Euphrates, but he wished also to make it an exclusive worship and Aton the sole god. This latter idea, already favored by Eduard Meyer and others, has been opposed, especially by MASPERO $^{3}$ ), and the evidence for either view so far as I know has not been adduced. In the first place, we have a considerable religious literature belonging to this movement, in the hymns and other inscriptions at Amarna. Nowhere in this large quantity of material is any other than the sun-god, Aton, Harmachis, Re or Atum ever mentioned or depicted. Nowhere is the word "gods " ever employed. Such a state of affairs is inconceivable if the other gods were all recognized except Amon. Passing over the fact that Aton is often called "the sole god, beside whom there is no other " ; we proceed to evidence which as far as I know, has not been noticed. On the above tomb of Ramose, which shows the change from the Amenhotep to the Ikhenaton régime, the word "gods" has everywhere been carefully expunged! Not merely the names of other gods, but the word "gods" itself has been thus treated. This is very significant. I have found this same erasure of the word "gods " at Karnak in the long offering inscription of Amenhotep III. on the east side of the third pylon, and also in the long coronation inscription of Thutmose III., throughout both. Likewise on a number of XVIIIth dynasty stelae in Europe it has been erased ${ }^{4}$ ). Now, I repeat, the above erasures concern only the word "gods" showing clearly a well defined hostility toward the idea which it connotes. On the erasure of particular names of gods other than Amon, compare the notes of Lepsius as far back as the days of his great expedition, sixty years ago: "Auch hier [temple of Ptah, northern Karnak] waren die Namen des Ptah und Amon wie auch der Hathor und ihre Figuren alle ausgekratzt; so auch auf dem Architrav der 'Türe die Namen des Ptah. Ebenso sind sämtliche Götter im Tempel zu Medinet Habu und in dem hinteren Teile des grofsen Tempels von Karnak ausgekratzt; die Götterverfolgung muls also nicht nur dem Amon gegolten haben, sondern viel allgemeiner gewesen sein ${ }^{5}$ )". It could

1) The genetive $n$ after 0 , will be found in the name of the Hermonthis temple, no. 5 below.

2) The latter actually occurs in the name of Seti I.'s mortuary temple at Kurna (LD. III, 131e. $150 a .151 b$ ), and one of Ramses 1I. also in a rock inscription at Gizeh (LD. III, 142i; see also LD. V, 9, and Birce, PSBA. 8, 201).

3) Hist. II, 325 n. 1.

4) I am unable at the moment to put my hand upon my collected references, but I remember distinctly a stela without a number, in a window seat on the north side of the main hall of the Louvre.

5) LD. Text III, 8; for details of Karnak see p. 31. The fact that at the Speos Artemidos only the name of Amon is erased, is easily explained by recollecting that the conflict clearly began 
hardly be expected that the names of all the gods could, within the limits of one reign be completely rooted out. Moreover the inscriptions of the temples of Lower Egypt have utterly perished. What do we know of Ikhenaton's treatment of the Memphite temple inscriptions for example? We can prove nothing from them for they have perished; but judging from Ikhenaton's treatment of the. Karnak temple of Ptah, there is no doubt as to what we should find had his Memphite temples survived ${ }^{1}$ ). There is an interesting evidence of the banishment of $W p$-w3wt, to be obtained by comparing a Leyden stela $(\mathrm{V}, 26)$ with a Vienna stela $(\text { No. 53) })^{2}$ ). On the Leyden stela we find that the wife of a certain \{ 1 mm 4 mm a

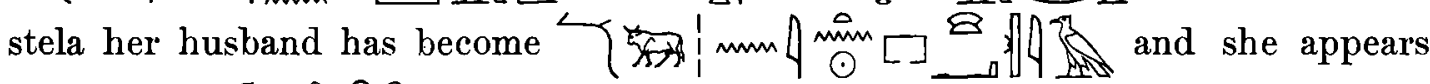
as merely $\circ$. When her husband enters the service of the Aton temple, it is no longer possible for her to be a musician of clear from all this evidence that Ikhenaton's movement demanded not less than monolotry. But when me remember that the hymns extend Aton's government throughout the then known world, on land and on sea alike, it becomes more than monolotry, more than henotheism; it becomes monotheism, in so far as monotheism was possible in that remote age. The philosophical monotheism of the modern world was of course a psychological impossibility in Ikhenaton's time; but he did introduce the earliest form of monotheism, with those necessary limitations of the term (which do not however forbid its use) as they have been recognized by such students of comparative religion as THrese.

It may be useful here to collect the references to the Aton temples, erected by Ikhenaton. As far as known to me they are the following:

\section{A. In Egypt.}

1. Thebes; called: called $\operatorname{co}_{\square}\left(\min _{\odot}^{4}\right)$ while on a Vienna tombstone it is called $\left.\left.4 \min _{\odot} \square\right]^{5}\right)$; and in the building inscription at Silsileh $\left.{ }^{6}\right)$ :

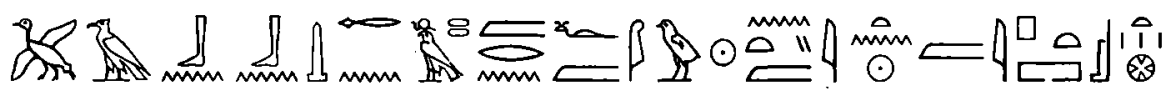

with Amon, and the Amon persecution began first; in that of the other gods, which followed, the little Speos Artemidos was overlooked or not yet reached.

1) See also Stela of Ptah, Comptes rendus, 1900, tome I, p.113-123.

2) See Baillér, Notice sur la collection égyptienne de l'abbé Desnoyers, p. 40, and Rec. XXIII, 144; also Bergmann, Rec.IX, 42. Baileft shows clearly the promotions in the fainily, proving the Leyden stela is the older.

3) Tomb of Ramose. My own copy, and Bourian', Rev. arch. 1882 n. s. XXIII p. 283.

4) Daressy, Annales II 2-4.

5) Bergmane, Rec. IX, 42-43; and Balleet, Rec. XXIII, 144.

6) LD. III, $110 i$. 
It probably stood near the southern Karnak pylons, in which fragments of it have been found ${ }^{1}$ ). Borchard states $^{2}$ ) that a temple of Aton existed in Luxor; but for this, the existence of fragments of the Aton temple in the Luxor temple is hardly sufficient evidence.

2. Amarna:

a) The state temple called: $\square / 4 \min _{\odot} \circ \min ^{3}$ ). It is of course the larger of the two temples at Amarna ${ }^{4}$ ).

b) The temple of the queen-mother, called $\left.{ }^{5}\right)$ :

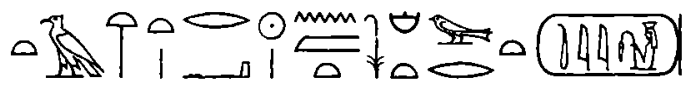

which must be the smaller of the two Amarna temples ${ }^{4}$ ).

c) The chapel of the princess Meretaton, called $\left.{ }^{6}\right)$ :

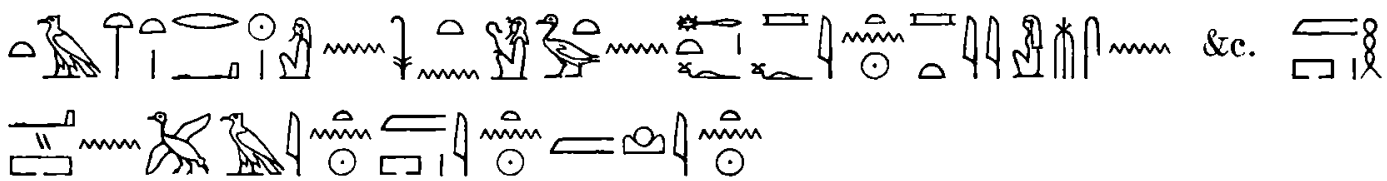

It was therefore "in the house (called): 'Rejoicing ${ }^{7}$ ) of Aton' " in the state temple, meaning probably within its enclosure.

"Shadow of Re " however was a designation which might be applied to any temple of Aton. This is seen from an unpublished hymn in the tomb of Merire (Amarna, no. 4), when placed parallel with a duplicate passage in the tomb of Apy (Amarna, no. 10), thus:

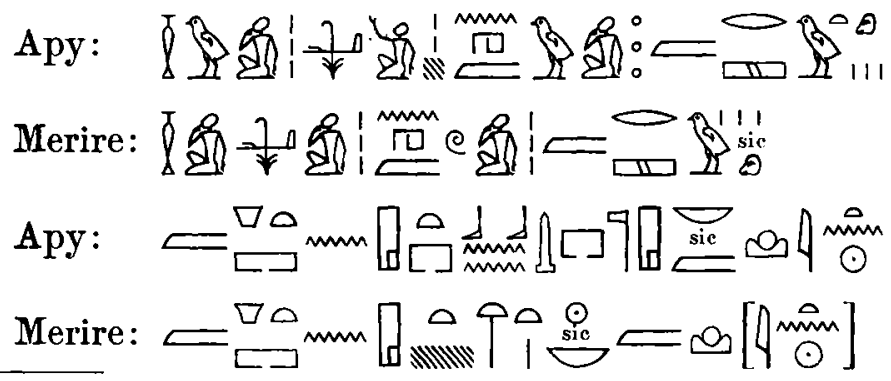

1) See Nestor L'hôte, Papiers inédits vol. III 80. 96. 97. 101. 104. 105 (ref. borrowed); Prisse, Trans. of Roy. Soc. of Lit. 2 nd ser. I, p. 76-92; Prisse, Mon. ég.V and XI; Perring, Trans. of Roy. Soc. of Lit. 2 nd ser. I, p. 140 ff.; LD. III, 110 c. g; Brugscz, Rec. de Mon. II 57, $2 a-k$; Bouriant, Rec. de Trav. VI 51 ff., and Pighi, ÄZ. 188441.

2) ÄZ. 34, 134; see Daressy, Notice explicative des ruines du temple de Louxor, Le Caire 1893, p. 4 and 21.

3) Passim in the Amarna tombs, e.g. LD. III, 109.

4) See Petrie, Tell-el-Amarna p.7 and pl. XXXV. $\uparrow_{1 \odot 1}^{0}$

5) LD. III, 102; see PSBA. XV, 213-214; also LD. III, 101, where it is called: $\square$

6) On an altar(?) block in the British Museum no.1000; published: Sharpe, Insc. II 48, and PSBA. XV, p. 209-211; also Trans. Royal Soc. of Lit. 2nd ser. 1 pl. II.

$\left.{ }^{7}\right)$ The house determinative is doubtless to be explained by the fact that it is the name of a building or hall. 
"The singers sing, rejoicing with joy in the broad hall of the house of the $b n b n$ of thy temple (thy shadow of Re) in Akhetaton. "The term "thy shadow of Re " being parallel with "the $b m b n$ of thy temple " is interchangeable with it and is evidently only a designation for the holy place of any Aton temple ${ }^{1}$ ).

d) There was also a building of the god at Amarna, called ${ }^{2}$ ):

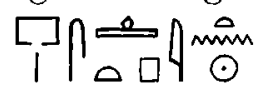

of which a certain $\rightleftarrows$ h 4 was overseer, and it may have been a chapel of Aton, belonging to the queen, for she is called \$ "who sends Aton to rest with a sweet voice $"$. But this is an idea common to the orthodox sun-hymns, and the dead often pray to be permitted to send $\operatorname{Re}$ to rest (śhtp).

The inscription of chief architect Bek, who built the state temple at Amarna is still preserved at Assuan ${ }^{4}$ ).

3. Heliopolis, called $\left.{ }^{5}\right): 4 \odot 1$ temples as priests of the Aton from this region are known under Amenhotep III. (Rec. VI, 52 f.).

4. Memphis, called ${ }^{6}$ : 口 was still in use in the time of Seti $I^{7}$ )

5. Hermonthis; called $^{8}$ ):

\section{B. In Nubia.}

6. At third cataract(?), called: $\square$ P 9 min, abbreviated to or $\square$ I (references above).

There are thus nine temples of Aton known with certainty and possibly eleven (counting Luxor and Hinatuna) ${ }^{9}$ ).

1) Temples called in Ramses III.'s time (Pap. HARRIS, 60, 8). Such a temple is also known under Ramses II. and in the 21st dyn.; see Spiegelberg (Rec. 17, 159f.), who thinks these later ones were in the necropolis.

2) Amarna tomb No.14, southern group; published by Daressy (Rec. XV, 38-41), who was unable to read the name; I found it as above in 1895.

3) Tomb of Ai, second long hymn (ll. 21-22); published by Daressy (Rec. XV, 46-47).

$\left.{ }^{4}\right)$ Mar., Mon. div. $26 u=$ Morgan, Cat. de Mon. I p. 40 no.174; neither is accurate and the relief faces opposite directions in the two publications.

$\left.{ }^{5}\right)$ Rec. 16, p. 123, CIX.

6) Spiegelberg, Rechnungen XVI 1. 4; Mar., Mon. div. $56=$ Rougé, Inscr. hiér. 54; Sir Charles Nicholson, "On Some Remains of the Disk Worshippers Discovered at Memphis «, Trans. of the Royal Soc. of Lit. (read May, 20, 1868), and ibid. vol. VIII, p. 308; also Bouriant, Rec. de Trav. VI p. 52-53. Finally Mar., Mon. div. $34 e$.

7) Spiegelberg, l. c.

8) Rec. 23, 62 .

9) The remains of sculptures of Ikhenaton on a single block found by PETRIE at Gurob may possibly indicate an Aton temple there (Perrie, 1ll. Kahun and Gurob, PI. XXIV 10). The altar block seen by Prisse at Eshmunen (Prisse, Rev, arch. 1844, p.730, letter to Champolion) may easily have been carried there from Amarna. 


\section{Addendum.}

According to the Canopics just published by Legrarn (Annales IV, p. 17-19 of tirage à part), there was an Aton quarter in Thebes, called "City of Aton

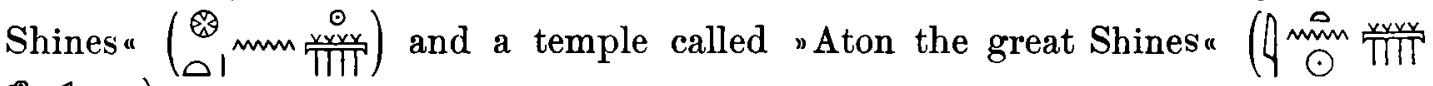
Sर्य . Whether these were but designations of Amenhotep IV.'s Theban temple and its quarter, is not certain; but such was in all probability the case.

\section{Besoldungsverhältnisse von Priestern im mittleren Reich.}

\section{Von Ludwig Borchardt.}

Die wertvollen Urkunden des zweiten Papyrusfundes von Illahun ${ }^{1}$ ) werden im Berliner Museum jetzt geglättet und unter Glas gebracht, so dafs die endgültige Veröffentlichung des sehr umfangreichen Materials wohl bald keine zu grofsen Schwierigkeiten mehr haben wird. Da aber immerhin noch einige Zeit vergehen dürfte, bis alle Fachgenossen aus dieser neuen Quelle für die Kulturgeschichte des mittleren Reiches werden schöpfen können, so möchte ich hier vorläufig wenigstens ein Dokument aus diesem Funde besprechen, das interessant genug ist, so vorweg genommen zu werden. Es klärt uns nämlich mit mathematischer Klarheit über die Besoldungsverhältnisse der Priester am Tempel von Illahun auf und läfst also wohl auch Schlüsse auf ähnliche Verhältnisse an anderen ägyptischen Tempeln zu. Es ist derselbe Papyrus - jetzt P.10005 -, aus dem ich schon früher ${ }^{2}$ ) die Liste des Tempelpersonals herauszog, und dabei den Unterschied zwischen ständigen Priestern und monatlich wechselnden Laienpriestern zeigen konnte. Am Anfang des beiderseitig abgerissenen Blattes steht das Ende einer Opferliste, dann folgen einige Zeilen mit den Namen der durch Zahlen unterschiedenen ganze Blatthöhe durch die hier folgende Aufstellung der Ein- und Ausgaben des Tempels, sowie der Verteilung des Restbestandes an die amtierenden Priester und Tempeldiener eingenommen. Die am unteren Rande stehenden Nebenrechnungen, die nur als Multiplikations- und Divisionsexempel Interesse hätten, können wir wohl übergehen.

1) $\ddot{A Z Z . ~ 1899, ~ S . ~} 89 \mathrm{ff}$.

2) ÄZ. 1899, S. 94. 